\title{
EFFECT OF IRRIGATION INTERVALS AND SOME ANTITRANSPIRANTS ON GROWTH AND YIELD OF SNAP BEAN (PHASEOLUS VULGARIS L) UNDER DRIP IRRIGATION SYSTEM IN CLAY LOAM SOIL
}

\author{
Mona S. A. Gaafar and Fahima H. Ayoub \\ Veg. Res. Dept. Hort. Res. Inst., Agric. Res. Cent., Egypt. \\ Received: Jul. 28 , 2018 \\ Accepted: Aug. 13,2018
}

\begin{abstract}
The objective of this work is to reduce the quantity of water applied by irrigation, increase the water use efficiency and determine the appropriate period for irrigation snap bean, a field experiment was implemented at the Experimental Station of Vegetable Research Department, Horticulture Research Institute, Agriculture Research Center, Giza Governorate, during the two growing summer seasons of 2016 and 2017. This study involved three irrigation intervals (2, 4 and 8 days) under clay loam soil using drip irrigation system, with spraying the plants by five antitranspirant substances (control, kaolin at $3 \mathrm{~g} / \mathrm{L}, \mathrm{MgCo}_{3}$ at $3 \mathrm{~g} / \mathrm{L}$, liquid paraffin $2 \%$ and bentonite $2 \%$ ), The results showed that increasing irrigation intervals from 2 days to 8 days decreased the total water content in the leaves, the rate of relative transpiration, whereas caused an increase in the leaf water deficit. While, reducing the irrigation interval from 8 days to 2 days led to a significant increase in vegetative growth parameters i.e. plant height, number of branches, number of leaves, leaf area and plant weight, but dry matter percent was decreased. The yield and pods quality of the plants irrigated every 2 days showed higher values and best quality than the other periods of irrigation, the highest values of $N, P$ and $K$ content in the pods and chlorophyll in the leaves were found with irrigation every 2 days. Spraying snap bean plants with $\mathrm{MgCO}_{3}$ followed by spraying with kaolin led to the highest total water content, the lowest relative transpiration and the lowest leaf water deficit. The best growth characters, yield and pods quality, $N, P$ and $K$ concentrations and chlorophyll content were obtained from the plants sprayed by $\mathrm{MgCO}_{3}$ followed by spraying with kaolin. On the other hand, the interactions treatments between irrigation intervals and antitranspirants resulted in a significant effect in many studied parameters whereas, the superior treatment for obtained strong vegetative growth, high pods yield with best quality was the interactions between irrigation every 2days and spraying the plants with $\mathrm{MgCo}_{3}$ at $3 \mathrm{~g} / \mathrm{L}$ three times, the first one at vegetative growth stage (at 3-4 true leaf stage) and the others after two weeks interval of the first one.
\end{abstract}

Key words: Snap bean, drip irrigation, irrigation intervals, antitranspirants kaolin, $\mathrm{MgCO}_{3}$, liquid paraffin Bentonite

\section{INTRODUCTION}

Snap bean (phaseolus vulgaris, L.) is one of the important economic vegetable crops grown in Egypt for local consumption and for foreign exportation markets. Many factors affecting snap bean production, including cultivars, weather conditions, planting date, nutrition and irrigation. Snap bean plants are sensitive to the changes in the soil moisture content and the decrease of water irrigation level (water stress), leading to significant reduction in pods quantity and quality.

Water management in green bean production is extremely important at all growth stages of plant development which due to its influence on stand establishment, pod set and its quality. For this reason, the crop must be 
supplied with adequate water to ensure vigorous growth. Irrigation is considered very important for its plant growth and pod improvement (Smesrud et al., 1997).

The irrigation scheduling techniques is very critical under using the drip irrigation whereas it is most efficiency and more controllable in irrigation system because excessive amount of the irrigation causes a decrease in the yield, inadequate irrigation results in a water stress and causing reduction in the production in this regard several investigators i.e. Wakrim et al., 2005 on common bean; Onder et al., 2006 and Sezen et al., 2008 on green bean which they reported that, yields decreased significantly if the irrigation interval increased. With drip irrigation systems, water and nutrients can be applied directly to the crop at the root zone, having positive effects on yield and water saving (Phene and Howell, 1984; Bozkurt et al., 2006). For these reasons, drip irrigation systems have seen widespread use in the world in recent years. Moreover, drip irrigation reduces deep percolation and evaporation and controls water status of the soil more precisely within the crop root zone (Singandhupe et al., 2003).

Transpiration means that losses of water by evaporation from the leaves through the stomata. The main source of water for the plants is soil water. It is taken up by roots hair cells by osmosis. Once the water moves through the root hair cells, by osmosis from cell to cell through the endodermis into the Xylem. The water is then pulled under pressure through the transpiration stream up the Xylem (a long hollow tube) to the leaves.

Several investigators reported that using foliar antitranspirants sprays may reduce the rate of transpiration through three ways: 1. Reflecting materials, such as kaolin clay, reduce absorption of radiant energy and thereby reduce leaf temperatures and transpiration (Bittelli et al., 2001; Erez and Glenn 2004; Gaballah and Moursy, 2004; Moftah and AlHumaid, 2005); 2. Film forming antitranspirants such as emulsions of wax, latex or plastics dry on foliage to form a thin transparentfilm, providing a physical barrier over some, not all stomata. This hinders escape of water vapor from leaves and also reduces water losses through guttation. 3. Certain chemical compounds such as magnesium carbonate which it can prevent stomata from opening fully by affecting stomatal guard cells, decreasing losses of water vapor (Davenport et al., 1974, Han, 1990; Steinberg et al., 1990; Nermeen and Shalaby (2011)

Asli and Neumann (2009) found that external colloidal suspensions of either naturally derived bentonite clay particles could significantly reduced water transport through the intact epidermal surfaces by up to $40 \%$.

The advantage of antitranspiriants causing increase the water potential of the plant by reducing water loss from soil; at the time, the plant growth depends on the water status of the plant more than depends on photosynthesis. In addition to reduce the amount of water consumption it was found that, spraying cucumber plants with liquid paraffin $2 \%$ concentration (once, twice or three times), led to a significant increase in total water content of the leaves, plant yield, number of fruits per plant and fruits total yield Khalel, 2003.

The objective of the present investigation was to study the effect of irrigation intervals and some antitranspirants compounds as well as their interactions on growth, pod yield and quality of snap bean plants cultivated under drip irrigation system in clay loam soil as well as enhancing water use efficiency. 


\section{MATERIALS AND METHODS}

Two field experiments were carried out during the two growing summer seasons of 2016 and 2017 at the Experimental Station of Vegetable Research Department, Horticulture Research Institute, Agriculture Research Center, Giza Governorate, to investigate the effect of irrigation intervals and some anti-transpirants compounds on growth and yield of snap bean (phaseolus vulgaris L) cv. Polista under drip irrigation system in clay loam soil. The physical and chemical properties of the experimental soil are presented in Table (1).

This experiment included three irrigation intervals i.e. 2, 4 and 8 days under drip irrigation system and spraying the plants by five antitransparent substances namely:

(1) Control treatment (spraying with water).

(2) Spraying with kaolin at $3 \mathrm{~g} / \mathrm{L}$.

(3) Spraying with $\mathrm{MgCO}_{3}$ at $3 \mathrm{~g} / \mathrm{L}$.

(4) Spraying with liquid paraffin $2 \%$.

(5) Spraying with bentonite $2 \%$.

Spraying with antitranspirant compounds were done three times: the first one at vegetative growth stage (at 34 true leaf stage) and the others after two weeks interval from the first one. Bean seeds were sown on $15^{\text {th }}$ of February at
2016 and 2017 seasons. The design of the experiment was split- plot system with 3 replicates where irrigation intervals were distributed in the main plots and the foliar application of antitranspiration compounds beside the control were arranged in the sub plots. The plot area was $8.4 \mathrm{~m}^{2}$ where consisted of 4 rows, each row was $3 \mathrm{~m}$ length and $70 \mathrm{~cm}$ width. Three seeds were sown per hill at $15 \mathrm{~cm}$ a part and the growing plants were thinned to one plant after 20 days from sowing. After 21 days from seed sowing the other agricultural practices took place according to the recommendation of Ministry of Agriculture.

\section{Data recorded:-}

1: Vegetative growth parameters:

Sample of 5 plants, from each sub plot were taken at 50 days after sowing (flowering stage) to determine the following data:

1- Plant height (cm).

2- Number of leaves per plant.

3- Number of branches per plant.

4- Leaf area $\left(\mathrm{cm}^{2}\right)$ measured by Li-300 leaf area meter produced by Li-Cor, Pinclivania.

5- Total fresh weight of vegetative parts of the plant (leaves + stems).

6- Dry matter \%.

Table (1): Physical and chemical properties of the experimental soil.

\begin{tabular}{|c|c|c|c|c|c|c|c|c|c|c|c|c|c|c|}
\hline \multicolumn{6}{|c|}{ Physical properties } & \multicolumn{8}{|c|}{ Chemical properties } & \multirow{3}{*}{\begin{tabular}{|c}
$\begin{array}{c}\text { Bulk } \\
\text { density }\end{array}$ \\
$\mathrm{g} / \mathrm{cm}^{3}$ )
\end{tabular}} \\
\hline \multicolumn{3}{|c|}{$\begin{array}{l}\text { Practical size } \\
\text { distribution }\end{array}$} & \multirow[t]{2}{*}{ Texture } & \multirow[t]{2}{*}{$\mathrm{pH}$} & \multirow{2}{*}{\begin{tabular}{|c|} 
EC \\
Ds/m
\end{tabular}} & \multicolumn{3}{|c|}{ Cation meq/l } & \multicolumn{3}{|c|}{ Anion meq/l } & \multirow{2}{*}{\begin{tabular}{|c|}
$\begin{array}{c}\text { Field } \\
\text { capacity }\end{array}$ \\
$\%$ \\
\end{tabular}} & \multirow{2}{*}{\begin{tabular}{|c}
$\begin{array}{c}\text { Available } \\
\text { water }\end{array}$ \\
$\%$
\end{tabular}} & \\
\hline Sand & Silt & Clay & & & & $\mathrm{Ca}^{++}$ & $\mathrm{Mg}^{++}$ & $\mathrm{Na}^{++}$ & $\mathrm{K}^{-}$ & $\mathrm{HCO}_{3}^{-}$ & $\mathrm{SO}_{4}^{--}$ & & & \\
\hline \multicolumn{14}{|c|}{2016} & \\
\hline 23.25 & 16.4 & 60.3 & Clay & 7.8 & 2.29 & 32.01 & 17.55 & 11.253 & $1 . .15$ & 1.0 & 0.62 & 28.6 & 12.8 & 1.43 \\
\hline \multicolumn{14}{|c|}{2017} & \\
\hline 23.30 & 17.2 & 59.5 & Clay & 7.4 & 2.25 & 31.86 & 17.81 & 11.28 & 1.45 & 1.1 & 0.60 & 28.2 & 12.4 & 1.38 \\
\hline
\end{tabular}


2: Water status of the plant:

a- Total water content (TWC) of the leaves: it was registered after 2 days from the third spraying of antitranspirants using the following equation:

$\mathrm{TWC} \%=$ (wet weight - dry weight $) /$ wet weight $\times 100$

b- Relative transpiration (RT): it was measured by taking a fixed area (100 $\mathrm{cm}^{2}$ ) of the leaves and an equal water surface in glass dishes; the samples were left at $30{ }^{\circ} \mathrm{C}$ for $6 \mathrm{~h}$ period and then measured the loss weight from each, using the following equation to calculate the relative transpiration:

RT = (weight of water loss from plant leaves/weight of water loss from water surface) $\times 100$

c- Leaf water deficit (LWD): it was estimated by weighing the plant leaves tooken randomly at the early morning (wet weight); then placed on the surface of distilled water for $1 \mathrm{~h}$ until saturated and then weighed again (saturated weight); then dried in oven and Weighed (dry weight). The LWD was calculated as follows:

LWD\% = (saturated weight - wet weight $) /$ (saturated weight - dry weight) x 100

3- Yield and Pods quality:

1- Total pods yield(kg/feddan)

2- Pod length (cm).

3- Pod diameter (cm).

4- Pod fresh weight (g).

5- Pod dry weight (g)

4- Chemical contents in the leaves and pods:

Total chlorophyll of the third leaf from the plant top was measured using chlorophyll meter (SPAD).

At the second harvest, random samples of green pods were taken from each plot and oven dried at $70^{\circ} \mathrm{C}$ till constant, the dry matter was then finally ground to determine nitrogen, phosphorus and potassium concentrations by the method described by Plummer (1971) Brown and Lilliand (1964) and Jackson (1973), respectively.

\section{Statistical analysis:}

The obtained data were subjected to the analysis of variance procedure and means and compared using the L.S.D. method at $5 \%$ level of significance according to Gomez and Gomez (1984).

\section{RESULTS AND DISCUSSION}

1-Vegetative growth parameters: 1-a-Irrigation intervals

The data in Table (2) shows that, reducing the irrigation interval from $8 \mathrm{~d}$ to 2 days led to a significant increase on vegetative growth parameters i.e. plant height from $27.47 \mathrm{~cm}$ to $31.8 \mathrm{~cm}$ and $28.27 \mathrm{~cm}$ to $32.27 \mathrm{~cm}$, number of branches per plant from 3.73 to 5.53 and 3.97 to 5.80 , number of leaves/plant from 13.6 to 20.07 and 14.09 to 20.53, plant weight from $28.6 \mathrm{~g}$ to $56.67 \mathrm{~g}$ and $30.67 \mathrm{~g}$ to 60.20 $\mathrm{g}$ and leaf area from $126.25 \mathrm{~cm}^{2}$ to 155.47 $\mathrm{cm}^{2}$ and $130.30 \mathrm{~cm}^{2}$ to $159.56 \mathrm{~cm}^{2}$ at the two seasons, respectively during the two seasons. Conversely, dry matter percent was decreased by reducing the irrigation interval from 8 days to 2 days. These results correspond with finding of Ramadan and Omar (2017) they indicated that frequent irrigation with $100 \%$ replenishment of evaporation losses resulted in the highest vegetative growth parameter of cabbage. On other hand, the dry matter percentage recorded a negative liner.

The obtained results clearly indicated that, the irrigation at shorter period resulted more vigor plants if compared with that plants which received it's needed from water requirements at longer period. It is well known that supplying the plants with adequate moisture may accede rate the physiological processes in the plant. 
Effect of irrigation intervals and some antitranspirants on growth and .........

\begin{tabular}{|c|c|c|c|c|c|c|c|c|}
\hline 惫- & 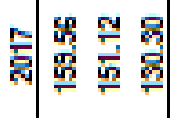 & क्2 & 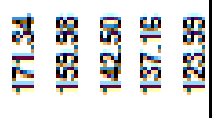 & के & 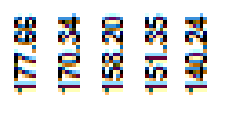 & 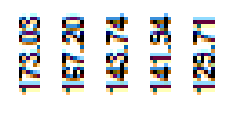 & 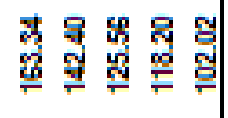 & in \\
\hline 洗 & 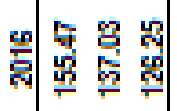 & సิ & 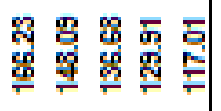 & कू. & 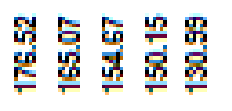 & 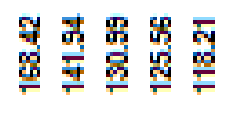 & 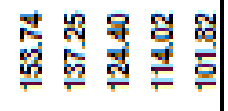 & 영 \\
\hline 昰 & 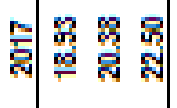 & 형 & 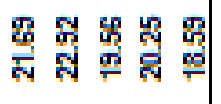 & 형 & 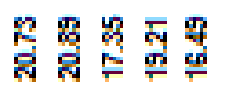 & 荧 & 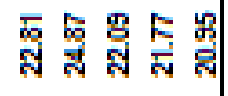 & $\exists$ \\
\hline ह & 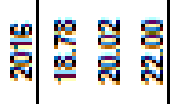 & के & 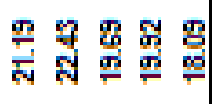 & \% & 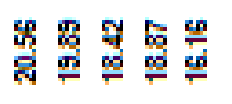 & 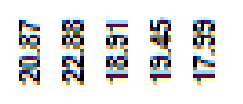 & 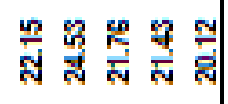 & g \\
\hline 营 & 숴웡ㅇㅇㅇ & 융 & 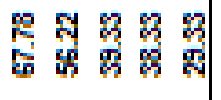 & के & 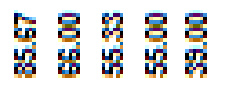 & 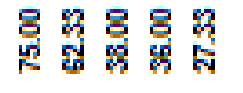 & 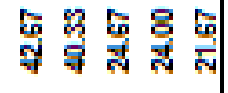 & 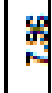 \\
\hline 鹿 & 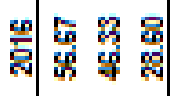 & गे & 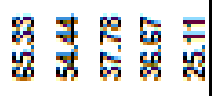 & 敢 & 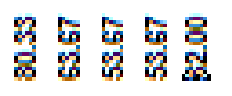 & 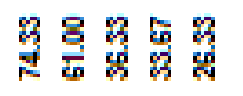 & 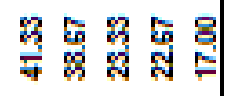 & 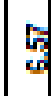 \\
\hline 䱱 & 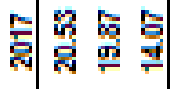 & \% & 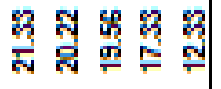 & : & 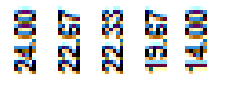 & 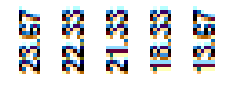 & 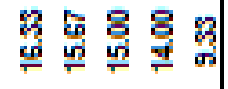 & 7 \\
\hline 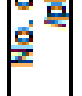 & 월혈 \% & क् & 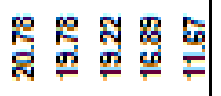 & 영 & 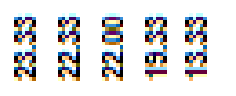 & 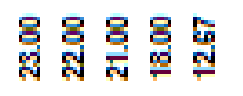 & 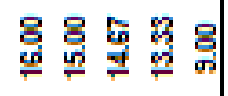 & 각 \\
\hline 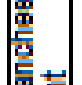 & 氛兽宫 & कै & 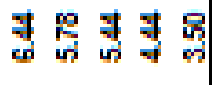 & के & 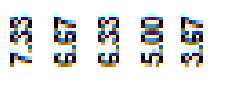 & 总 乌్ 8 & 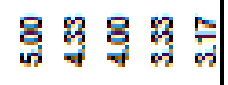 & 政 \\
\hline 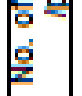 & 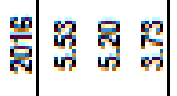 & 영 & 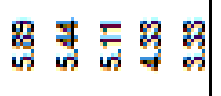 & g) & 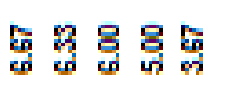 & ஜु & 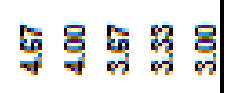 & 영 \\
\hline 营 & 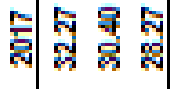 & 연 & 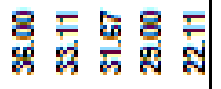 & : & 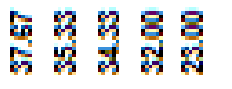 & 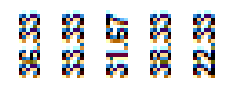 & 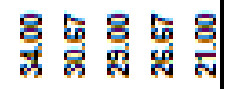 & 7 \\
\hline 臣 & 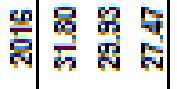 & 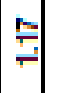 & 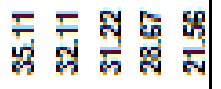 & की & 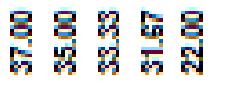 & 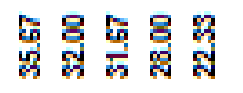 & 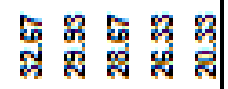 & 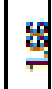 \\
\hline & & & & & 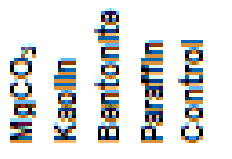 & 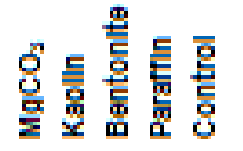 & 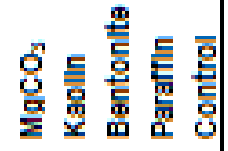 & \\
\hline $\begin{array}{l}\text { 罳 } \\
\text { 垔 } \\
\text { 暍 }\end{array}$ & 罱署㗄 & 总 & 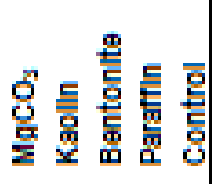 & 䇣 & 罯 & 罾 & 䍠 & a \\
\hline
\end{tabular}


Moreover, it increase translocation of metabolites which in turn, increased the accumulation of organic compounds in the plants. It could be concluded that, the reduction in plant growth measurements was pronounced when snap bean were subjected to high soil moisture stress. Such response might be attributed to lack of water absorption, inhibition of meristemic activity and reduction in photosynthetic efficiency under the prolonged irrigation interval. However, the reduction in leaves and branches numbers and weights might be due to the reduction in assimilates translocated to new developed leaves and shoots were not enough to maintain or develop these organs (Fayza et al., 2013)

\section{1-b-Antitranspirant compounds}

it was found from the data in Table (2) that, spraying snap bean plants with different antitranspirant compounds play an important role which markedly affected vegetative growth of snap bean as a result of application antitranspirants which has a significant effect on plant height, No. of branches, No. of leaves per plant, plant weight, dry matter $\%$ and leaf area. The best growth characters were produced in plants which sprayed by $\mathrm{MgCO}_{3}$ followed by spraying the plants with kaolin. The effect of antitranspirants in plant growth is recognize through improving water potential of the plant in the stage that plant growth supports on the water status more than photosynthesis. This increase in the growth will produce a good leaf area, which stimulate photosynthesis. These results are in harmony consistent with Abd El-Aal et al., (2008) on eggplant and Khalel (2015) on potato, they reported that, spraying the plants with antitranspirant led to a significant increase in vegetative growth parameters. 1-c - The interactions effect

Effects of the interactions between irrigation intervals and antitranspirants on vegetative growth are presented in Table (2). The data cleared that the best growth characteristics were obtained in the plants which irrigated every $2 \mathrm{~d}$ with spraying these plants by $\mathrm{MgCO}_{3}$ which it is consider the superior over many other interaction treatments in the first and the second seasons under investigation. All physiological process like photosynthesis, transpiration, cell turgidity and tissue growth in plants are directly affected by availability water. This means that the products of photosynthesis are being used more rapidly for growth to occur, photosynthesis must be greater than respiration under this case.

\section{2- Water status of the plants \\ 2-a- Irrigation intervals}

The results presented in Table (3) show the effect of irrigation intervals on water status of snap bean plants. The increase in irrigation interval from 2 days to 8 days led to a significant decrease in the total water content of the leaves from $79.9 \%$ to $71.21 \%$ and $80.33 \%$ to $71.60 \%$, respectively, the rate of relative transpiration from $0.35 \%$ to $0.26 \%$ and $0.37 \%$ to $0.27 \%$ during the first and the second seasons respectively, while the leaf water deficit increased from $27.56 \%$ to $32.13 \%$ and $27.86 \%$ to $32.70 \%$ during the first and the second seasons, respectively.

The reduction in total water content of the leaves and relative transpiration rate, and the increase in leaf water deficit, when prolonged the irrigation period from 2 days to 8 days, may be due to the low content of the soil moisture, especially in the surface layer of the soil where the distribution of most snap bean roots are found in this zone which lead to exposure the plants to water stress and reduce the efficiency of water absorption 
Effect of irrigation intervals and some antitranspirants on growth and .........

through plant roots and thus lead to a decline in the total water content of the leaves and the relative transpiration rate. These findings results are in harmony with Khalel, 2015 which he reported that, the increase in irrigation interval from $3 \mathrm{~d}$ to 6 days decreased the total water content of the leaves and the rate of relative transpiration while, the leaf water deficit increased in potato.

Table 3: Effect of irrigation intervals and spraying with some antitranspirant compounds on water status of snap bean plants

\begin{tabular}{|c|c|c|c|c|c|c|c|}
\hline \multirow{2}{*}{\multicolumn{2}{|c|}{ Treatments }} & \multicolumn{2}{|c|}{$\begin{array}{c}\text { Total water } \\
\text { content TWC\% }\end{array}$} & \multicolumn{2}{|c|}{$\begin{array}{c}\text { Relative } \\
\text { transpiration rate } \\
\text { LT\% }\end{array}$} & \multicolumn{2}{|c|}{$\begin{array}{c}\text { Leaf water deficit } \\
\text { LWD\% }\end{array}$} \\
\hline & & 2016 & 2017 & 2016 & 2017 & 2016 & 2017 \\
\hline \multirow{3}{*}{\multicolumn{2}{|c|}{$\begin{array}{l}\text { 2days } \\
\text { 4days } \\
\text { 8days }\end{array}$}} & 79.90 & 80.33 & 0.35 & 0.37 & 27.56 & 27.86 \\
\hline & & 76.38 & 76.35 & 0.28 & 0.28 & 27.82 & 27.98 \\
\hline & & 71.21 & 71.60 & 0.26 & 0.27 & 32.13 & 32.70 \\
\hline \multicolumn{2}{|c|}{ L.S.D. at $5 \%$} & 1.88 & 1.98 & 0.03 & 0.03 & 1.60 & 1.93 \\
\hline \multicolumn{2}{|l|}{$\mathrm{MgCO}_{3}$} & 80.50 & 80.70 & 0.24 & 0.25 & 22.31 & 22.44 \\
\hline \multicolumn{2}{|l|}{ Kaolin } & 77.78 & 78.13 & 0.28 & 0.29 & 29.93 & 29.96 \\
\hline \multicolumn{2}{|l|}{ Bentonite } & 75.87 & 76.46 & 0.27 & 0.28 & 30.32 & 31.02 \\
\hline \multicolumn{2}{|l|}{ Paraffin } & 74.17 & 74.48 & 0.33 & 0.34 & 30.66 & 31.14 \\
\hline \multicolumn{2}{|l|}{ Control } & 70.83 & 70.70 & 0.38 & 0.39 & 32.63 & 33.01 \\
\hline \multicolumn{2}{|c|}{ L.S.D. at $5 \%$} & 1.65 & 1.75 & 0.02 & 0.03 & 1.85 & 1.84 \\
\hline \multirow{5}{*}{ 2days } & $\mathrm{MgCO}_{3}$ & 84.35 & 84.79 & 0.27 & 0.28 & 20.72 & 21.06 \\
\hline & Kaolin & 80.69 & 81.54 & 0.29 & 0.30 & 25.52 & 25.56 \\
\hline & Bentonite & 79.00 & 79.37 & 0.32 & 0.34 & 30.37 & 30.79 \\
\hline & Paraffin & 79.02 & 79.30 & 0.43 & 0.43 & 30.33 & 30.70 \\
\hline & Control & 76.44 & 76.67 & 0.48 & 0.48 & 30.86 & 31.19 \\
\hline \multirow{5}{*}{ 4days } & $\mathrm{MgCO}_{3}$ & 79.10 & 79.00 & 0.23 & 0.24 & 21.53 & 21.56 \\
\hline & Kaolin & 77.02 & 77.10 & 0.29 & 0.28 & 31.01 & 31.03 \\
\hline & Bentonite & 75.84 & 76.10 & 0.25 & 0.25 & 27.82 & 27.81 \\
\hline & Paraffin & 75.92 & 76.33 & 0.30 & 0.29 & 27.74 & 27.75 \\
\hline & Control & 74.02 & 73.20 & 0.35 & 0.35 & 31.02 & 30.75 \\
\hline \multirow{5}{*}{ 8days } & $\mathrm{MgCO}_{3}$ & 78.06 & 78.30 & 0.22 & 0.23 & 24.68 & 24.70 \\
\hline & Kaolin & 75.65 & 75.76 & 0.26 & 0.28 & 33.25 & 33.29 \\
\hline & Bentonite & 72.77 & 73.90 & 0.23 & 0.24 & 32.77 & 34.46 \\
\hline & Paraffin & 67.58 & 67.80 & 0.28 & 0.29 & 33.91 & 34.97 \\
\hline & Control & 62.02 & 62.23 & 0.31 & 0.33 & 36.02 & 36.09 \\
\hline \multicolumn{2}{|c|}{ L.S.D.at 5\% } & 2.85 & 3.04 & 0.04 & 0.06 & 3.20 & 3.19 \\
\hline
\end{tabular}




\section{2-b- Antitranspirant compounds}

Spraying the plants by some antitransparent compounds resulted in a significant increase in the total water content in the leaves as shown in Table (3) whereas, a significant decrease obviously noticed in the relative transpiration and the leaf water deficit compared with control. It may be due to the activity of these substances in partial closing of stomata, which helps in reducing the rate of transpiration and reducing water loss through stomata containing a waxy layer above it. This finding was mentioned by Davenport, 1977 and Abdallah et al., 1996, they told that, antitranspirants increased the total and relative water content of the leaves by reducing the rate of transpiration and water loss from the soil، increasing water use efficiency of the plant and improving plant growth, it is known that the plant growth depends on the water status of plant more than photosynthesis. This result is agreement with Gawish, 1992 on snap bean and Khalel, 2015 on potato, they found that spraying antitranspirants increased the total water content and decreased the relative transpiration and the leaf water deficit.

\section{2-c - The interactions effect}

Table (3) illustrate the effect of the interactions between irrigation intervals and antitranspirants on water status of snap bean plants. The highest total water content $(84.35 \%$ and $84.79 \%)$ were resulted from the interactions between irrigation every 2 days and spraying the plants with $\mathrm{MgCO}_{3}$. While the highest rate of relative transpiration $(0.48 \%)$ was found from the interactions between the irrigation every 2 days and without spraying with antitranspirants (control) which showed significantly superior over most than the other interactions during the first and the second seasons, respectively. The highest leaf water deficits $(36.02 \%$ and $36.09 \%)$ were obtained from the interactions between irrigation every 8 day with the control during the two seasons, respectively.

\section{3- Yield and Pods quality: \\ 3-a-Irrigation intervals}

Data in Table (4) show a significant effect of irrigation intervals on snap bean pods quality i.e. pod length, diameter, fresh and dry weight as well as pods yield. The yield and pods quality of plants irrigated every 2 days registered higher yield and best pods quality than the other periods of irrigation. Data in Table (4) showed also that reducing the irrigation interval from $8 \mathrm{~d}$ to $2 \mathrm{~d}$ led to a significant increase in the pod length from $10.83 \mathrm{~cm}$ and $11.09 \mathrm{~cm}$ to $12.69 \mathrm{~cm}$ and $12.71 \mathrm{~cm}$, pod diameter from $0.68 \mathrm{~cm}$ and $0.69 \mathrm{~cm}$ to $0.74 \mathrm{~cm}$ and $0.77 \mathrm{~cm}$, weight of the pod from $3.01 \mathrm{~g}$ and $3.39 \mathrm{~g}$ to $3.97 \mathrm{~g}$ and $4.37 \mathrm{~g}$, pod dry weight from $0.48 \mathrm{~g}$ and $0.50 \mathrm{~g}$ to $0.53 \mathrm{~g}$ and $0.55 \mathrm{~g}$ as well as yield from 3.26 and $3.59 \mathrm{ton} / \mathrm{fed}$ to 4.54 and $4.95 \mathrm{ton} / \mathrm{fed}$, respectively in the two seasons. A significant decline in the pods quality, average of pod weight, and total pods yield are shown when the irrigation interval increased from $2 \mathrm{~d}$ to $8 \mathrm{~d}$, and this reduction possibly was due to the reduction of soil moisture content and the water status of the plant as shown in (Table 3) which affected the absorption rate of nutrient elements from the soil Abu-Dahy and Al-Yuonis, 1988 and it was reflected in decreasing photosynthesis rate which reduced cell division and elongation and consequently reduced plant leaf area, activity of plant enzymes and hormones. Yasin. 1992: Khalel, 2015, reported that reducing the irrigation interval led to a significant increase in the plant yield and quality. 
Effect of irrigation intervals and some antitranspirants on growth and .........

Table 4: Effect of irrigation intervals and spraying with some antitranspirant compounds on Yield and Pods quality of snap bean plants

\begin{tabular}{|c|c|c|c|c|c|c|c|c|c|c|c|}
\hline \multirow{2}{*}{\multicolumn{2}{|c|}{ Treatments }} & \multicolumn{2}{|c|}{$\begin{array}{l}\text { Pod length } \\
\text { (cm) }\end{array}$} & \multicolumn{2}{|c|}{$\begin{array}{c}\text { Pod } \\
\text { diameter } \\
(\mathrm{cm})\end{array}$} & \multicolumn{2}{|c|}{$\begin{array}{l}\text { Pod weight } \\
\text { (g) }\end{array}$} & \multicolumn{2}{|c|}{$\begin{array}{c}\text { Pod dry } \\
\text { weight } \\
\text { (g) }\end{array}$} & \multicolumn{2}{|c|}{$\begin{array}{l}\text { Total yield } \\
\text { Ton/feddan }\end{array}$} \\
\hline & & 2016 & 2017 & 2016 & 2017 & 2016 & 2017 & 2016 & 2017 & 2016 & 2017 \\
\hline \multirow{3}{*}{\multicolumn{2}{|c|}{$\begin{array}{l}2 \text { days } \\
4 \text { days } \\
8 \text { days }\end{array}$}} & 12.69 & 12.71 & 0.74 & 0.77 & 3.97 & 4.34 & 0.53 & 0.55 & 4.54 & 4.95 \\
\hline & & 12.19 & 12.35 & 0.72 & 0.73 & 3.61 & 4.00 & 0.52 & 0.53 & 4.05 & 4.39 \\
\hline & & 10.83 & 11.09 & 0.68 & 0.69 & 3.01 & 3.39 & 0.48 & 0.50 & 3.26 & 3.59 \\
\hline \multicolumn{2}{|c|}{ L.S.D. at $5 \%$} & 0.28 & 0.27 & 0.04 & 0.02 & 0.38 & 0.28 & 0.01 & 0.02 & 0.21 & 0.07 \\
\hline \multicolumn{2}{|l|}{$\mathrm{MgCO}_{3}$} & 3.06 & 13.28 & 0.77 & 0.79 & 4.16 & 4.72 & 0.60 & 0.62 & 5.24 & 5.62 \\
\hline \multicolumn{2}{|l|}{ Kaolin } & 12.40 & 12.56 & 0.74 & 0.76 & 3.70 & 4.20 & 0.58 & 0.59 & 4.85 & 5.21 \\
\hline \multicolumn{2}{|c|}{ Bentonite } & 12.29 & 12.44 & 0.73 & 0.73 & 3.43 & 3.85 & 0.56 & 0.57 & 4.28 & 4.62 \\
\hline \multicolumn{2}{|c|}{ Paraffin } & 11.16 & 11.27 & 0.70 & 0.71 & 3.50 & 50 & 0.45 & 0.47 & 3.44 & 3.93 \\
\hline \multicolumn{2}{|c|}{ Control } & 10.60 & 10.71 & 0.62 & 0.66 & 3.06 & 3.31 & 0.36 & 0.39 & 1.99 & 2.18 \\
\hline \multicolumn{2}{|c|}{ L.S.D. at $5 \%$} & 0.31 & 0.28 & 0.03 & 0.04 & 0.27 & 0.23 & 0.01 & 0.02 & 0.29 & 0.22 \\
\hline \multirow{5}{*}{ 2days } & $\mathrm{MgCO}_{3}$ & 12.23 & 14.27 & 0.80 & 0.87 & 5.07 & 5.27 & 0.63 & 0.66 & 5.92 & 6.18 \\
\hline & Kaolin & 13.20 & 13.20 & 0.80 & 0.80 & 4.24 & 4.72 & 0.60 & 0.61 & 5.42 & 5.71 \\
\hline & Bentonite & 13.00 & 13.10 & 0.77 & 0.77 & 3.70 & 4.47 & 0.58 & 0.59 & 4.94 & 5.39 \\
\hline & Paraffin & 11.70 & 11.67 & 0.70 & 0.73 & 3.53 & 3.87 & 0.47 & 0.50 & 4.14 & 4.69 \\
\hline & Control & 11.30 & 11.33 & 0.63 & 0.67 & 3.30 & 3.40 & 0.39 & 0.39 & 2.28 & 2.78 \\
\hline \multirow{5}{*}{ 4days } & $\mathrm{MgCO}_{3}$ & 13.50 & 13.73 & 0.80 & 0.80 & 4.03 & 4.64 & 0.60 & 0.61 & 5.17 & 5.80 \\
\hline & Kaolin & 12.73 & 12.90 & 0.73 & 0.77 & 3.67 & 4.50 & 0.59 & 0.59 & 4.96 & 5.51 \\
\hline & Bentonite & 12.43 & 12.67 & 0.73 & 0.73 & 3.54 & 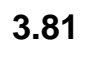 & 0.58 & 0.57 & 4.23 & 4.39 \\
\hline & Paraffin & 11.43 & 11.47 & 0.70 & 0.70 & 3.47 & 3.60 & 0.45 & 0.47 & 3.97 & 4.09 \\
\hline & Control & 10.83 & 10.97 & 0.63 & 0.67 & 3.33 & 3.47 & 0.36 & 0.39 & 1.93 & 2.16 \\
\hline \multirow{5}{*}{ 8days } & $\mathrm{MgCO}_{3}$ & 11.46 & 11.83 & 0.70 & 0.70 & 3.37 & 4.24 & 0.56 & 0.58 & 4.64 & 4.88 \\
\hline & Kaolin & 11.27 & 11.57 & 0.70 & 0.70 & 3.20 & 3.38 & 0.56 & 0.58 & 4.17 & 4.40 \\
\hline & Bentonite & 11.43 & 11.57 & 0.70 & 0.70 & 3.03 & 3.27 & 0.51 & 0.54 & 3.68 & 4.07 \\
\hline & Paraffin & 10.33 & 10.67 & 0.70 & 0.70 & 2.91 & 3.05 & 0.43 & 0.44 & 2.21 & 3.01 \\
\hline & Control & 9.67 & 9.83 & 0.60 & 0.63 & 2.53 & 3.03 & 0.34 & 0.38 & 1.59 & 1.60 \\
\hline \multicolumn{2}{|c|}{ L.S.D. at $5 \%$} & 0.53 & 0.49 & N.S & N.S & 0.47 & 0.40 & 0.02 & 0.03 & 0.38 & 0.5 \\
\hline
\end{tabular}




\section{3-b-Antitranspirant compounds}

Application of antitranspirant compounds as foliar spraying has a significant effect on pods quality and yield. The highest yield and best pods quality resulted from spraying the plants with $\mathrm{MgCO}_{3}$ followed by kaolin. The positive impact of spraying antitranspirants may be due to the active role of the waxy substance in maintaining the cells turgid and reducing water loss from the plant by partial closing of stomata and reducing the rate of transpiration (Davenport, 1977). It helps for keeping soil moisture, increasing water use efficiency (Abdallah, 1996) and keep continues of the normal rate of biological processes, especially photosynthesis, and this is reflected in the positive growth and yield of the plant.

\section{3-c - The interactions effect}

Data in Table (4) illustrate the effect of the interaction between irrigation periods and foliar spry by some antitranspirants in total yield and pods quality. The highest total yield of pods resulted from the interactions between irrigation every $2 \mathrm{~d}$ and spraying the plants by $\mathrm{MgCO}_{3}$. While no significant were found with the interactions in pod diameter. The effect of antitranspirants on plant growth is through improving water potential of the plant in the stage that plant growth supports on the water status more than photosynthesis. This increase in the growth will produce a good leaf area, which stimulate photosynthesis and that reflect on pods yield and its quality.

\section{3- Chemical Composition}

The effect of three different irrigation intervals and some antitranspirant compounds and their interaction on chemical composition are presented in Table (5).

\section{4-a-Irrigation intervals}

Concerning to the effect of different irrigation intervals on $\mathrm{N}, \mathrm{P}$ and $\mathrm{K}$ content in pods as well as chlorophyll contents in the leaves are shown in Table (5). The data illustrate that, the highest values of $N, P$ and $K$ content in the pods and chlorophyll in the leaves were found with irrigation the plants every 2 days, while the lowest values were found with irrigation every 8 days. It is well known that water plays a crucial role in the nutrient uptake, transportation and photosynthesis.

The reduction in levels of each $N, P$ and $K \%$ due to stress of irrigation intervals period in both seasons were ascertained by the work of Khalil et al. (2012); Ramadan and Omar, 2017, they found that when soil moisture decreased, the mobility of nutrient in the soil is towered and the rate of nutrients flow to root absorption zone decreased. Such reductions in their contents in different tissues were attributed primarily to soil water deficiency which markedly reduces the flow rates of elements from the soil to the plants, their absorption by stressed root cells and also its ability to translocate through the different organs and tissues within the plant (Sawhney and Singh, 2002). Also, Hassan et al. (2013) and Soha and Khalil (2015) recorded stimulatory effect of water on the absorbing efficiency of ions and their movement. Results of decreasing chlorophyll content under advanced water stress was similar to that reported by Prakash and Ramachandran (2000b) they postulated that moisture stress would have inhibited the biosynthesis of chlorophyll a precursor, which in turn would have reduced the total chlorophyll content and that reflect also on mineral uptake. 
Effect of irrigation intervals and some antitranspirants on growth and .........

Table 5: Effect of irrigation intervals and spraying with some antitranspirant compounds on chemical composition in the leaves and pods of snap bean plants

\begin{tabular}{|c|c|c|c|c|c|c|c|c|c|}
\hline \multirow{2}{*}{\multicolumn{2}{|c|}{ Treatments }} & \multicolumn{2}{|c|}{$\begin{array}{c}\mathrm{N} \\
(\%)\end{array}$} & \multicolumn{2}{|c|}{$\begin{array}{l}\mathbf{P} \\
(\%)\end{array}$} & \multicolumn{2}{|c|}{$\begin{array}{l}K \\
(\%)\end{array}$} & \multicolumn{2}{|c|}{$\begin{array}{l}\text { Chlorophyll } \\
\text { (SPAD) }\end{array}$} \\
\hline & & 2016 & 2017 & 2016 & 2017 & 2016 & 2017 & 2016 & 2017 \\
\hline \multicolumn{2}{|l|}{ 2days } & 2.61 & 2.69 & 0.75 & 0.77 & 1.19 & 1.22 & 45.01 & 45.59 \\
\hline \multicolumn{2}{|l|}{ 4days } & 2.53 & 2.58 & 0.69 & 0.71 & 1.14 & 1.18 & 41.82 & 42.29 \\
\hline \multicolumn{2}{|l|}{ 8days } & 2.39 & 2.40 & 0.61 & 0.62 & 1.07 & 1.11 & 37.20 & 37.91 \\
\hline \multicolumn{2}{|c|}{ L.S.D 5at \% } & 0.14 & 0.03 & 0.02 & 0.04 & 0.02 & 0.04 & 0.42 & 0.71 \\
\hline \multicolumn{2}{|l|}{$\mathrm{MgCO}_{3}$} & 2.87 & 2.90 & 0.98 & 1.00 & 1.30 & 1.33 & 43.93 & 44.64 \\
\hline \multicolumn{2}{|l|}{ Kaolin } & 2.72 & 2.75 & 0.69 & 0.70 & 1.21 & 1.23 & 42.02 & 43.03 \\
\hline \multicolumn{2}{|l|}{ Bentonite } & 2.48 & 2.51 & 0.64 & 0.66 & 1.15 & 1.19 & 41.38 & 41.87 \\
\hline \multicolumn{2}{|l|}{ Paraffin } & 2.4 & 2.42 & 0.62 & 0.62 & 1.09 & 1.14 & 40.34 & 41.00 \\
\hline \multicolumn{2}{|l|}{ Control } & 2.1 & 2.19 & 0.49 & 0.51 & 0.93 & 0.96 & 39.06 & 39.11 \\
\hline \multicolumn{2}{|c|}{ L.S.D.at 5\% } & 0.06 & 0.03 & 0.02 & 0.04 & 0.02 & 0.03 & 0.43 & 0.61 \\
\hline \multirow{5}{*}{ 2days } & $\mathrm{MgCO}_{3}$ & 2.95 & 2.99 & 1.12 & 1.14 & 1.36 & 1.39 & 47.40 & 47.70 \\
\hline & Kaolin & 2.77 & 2.80 & 0.74 & 0.77 & 1.25 & 1.27 & 46.03 & 46.50 \\
\hline & Bentonite & 2.57 & 2.72 & 0.68 & 0.70 & 1.21 & 1.22 & 44.77 & 45.20 \\
\hline & Paraffin & 2.49 & 2.57 & 0.67 & 0.68 & 1.13 & 1.15 & 43.96 & 45.10 \\
\hline & Control & 2.25 & 2.36 & 0.55 & 0.56 & 1.02 & 1.05 & 42.90 & 43.40 \\
\hline \multirow{5}{*}{ 4days } & $\mathrm{MgCO}_{3}$ & 2.88 & 2.91 & 0.99 & 1.02 & 1.30 & 1.33 & 43.88 & 45.37 \\
\hline & Kaolin & 2.70 & 2.76 & 0.68 & 0.69 & 1.21 & 1.23 & 42.72 & 43.93 \\
\hline & Bentonite & 2.45 & 2.51 & 0.61 & 0.64 & 1.15 & 1.21 & 42.57 & 42.83 \\
\hline & Paraffin & 2.42 & 5.43 & 0.65 & 0.65 & 1.11 & 1.16 & 40.53 & 40.83 \\
\hline & Control & 2.23 & 2.29 & 0.52 & 0.53 & 0.92 & 0.99 & 39.40 & 38.50 \\
\hline \multirow{5}{*}{ 8days } & $\mathrm{MgCO}_{3}$ & 2.77 & 2.79 & 0.83 & 0.85 & 1.24 & 1.27 & 40.50 & 40.81 \\
\hline & Kaolin & 2.66 & 2.69 & 0.64 & 0.65 & 1.18 & 1.21 & 37.30 & 38.64 \\
\hline & Bentonite & 2.43 & 2.31 & 0.63 & 0.64 & 1.08 & 1.13 & 36.80 & 37.57 \\
\hline & Paraffin & 2.29 & 2.27 & 0.53 & 0.54 & 1.03 & 1.11 & 36.53 & 37.09 \\
\hline & Control & 1.83 & 1.93 & 0.40 & 0.43 & 0.84 & 0.85 & 34.87 & 35.42 \\
\hline \multicolumn{2}{|c|}{ L.S.D.at 5\% } & 0.11 & 0.05 & 0.04 & 0.07 & 0.03 & 0.06 & 0.74 & 1.05 \\
\hline
\end{tabular}

\section{4-b-Antitranspirant compounds}

Regarding to the effect of antitranspirants application, data in Table (5) indicate significant increments on $\mathrm{N}$, $P$ and $K$ concentrations in the pods and chlorophyll content in the leaves comparing with the untreated plants in both seasons. In this regards foliar spraying of $\mathrm{MgCO}_{3}$ was the superior treatment followed by kaolin. On the other hand, untreated plants recorded the lowest nutrient concentrations in both seasons. The effect of foliar spray by antitranspirants recorded the better uptake of all nutrients compared to the control and this induced beneficial 
influence on growth (Table 1). The obtained results are consistent with the most previous investigators, which pointed out the same direct correlation between antitranspirants materials and some elemental nutrition in tissues of the plant (Ramadan and Omar, 2017). chlorophyll percentage increased by all treatments, these results were correlated with the vase life results, however, high concentration of chlorophyll in the treated plants could be due to the effect of anti-transpirant, in improving water use efficiency, by reducing leaf transpiration rate via increasing leaf reflecting or inducing stomata closure. These results are in agreement with those obtained by Rabiza-Świder and Skutnik (2004) they found that, postharvest longevity of Zantedeschia and Hosta was extended by inhibiting leaf senescence through delaying chlorophyll loss and soluble protein degradation. Nevertheless, Abd EI-Kader et al. (2006) recorded that spraying antitranspirants increased growth parameters. El-Abd (1996) on citrus, Ranney et al. (1989) on cherry trees recorded that pruning and antitranspirant were successful in delaying plant water stress, and relative growth rate.

\section{4-c - The interactions effect}

The effect of the interactions between different irrigation intervals and foliar application of antitranspirants on $\mathbf{N}, \mathbf{P}$ and $K$ and chlorophyll contents were illustrated in Table (5). The data showed that, there was a significant increase in $\mathrm{N}, \mathrm{P}$ and $\mathrm{K}$ content in green snap bean pods and chlorophyll in the leaves in both seasons as affected by foliar applications with different source of antitranspirants under different irrigation intervals in the both seasons. Plants sprayed with $\mathrm{MgCO}_{3}$ at (3\%) concentration under irrigation every $2 \mathrm{~d}$ recorded the highest values of the obtained parameters under these study compared with the other treatments. These results agree with that reported by
Abd-El-Aal et al. (2008) on eggplant and Ramadan and Omar, 2017 on cabbage

\section{CONCLUSIONS}

It can be concluded from this study that irrigation snap bean plants under using drip irrigation method at interval every two days is preferable to get the best water status for the plants, in addition to obtain the highest vegetative growth characteristics, exultant pod characteristics and the highest total yield per unit area. The uses of antitranspirants were contributed to improve water status of the plants and reduce water loss through transpiration, as a result of the partial closure of the stomata. It means that antitranspirants can be used for water lacking in arid and semi-arid regions, in addition to lowering the effect of water stress on growth and yield of plants. The superior treatments for obtain strong vegetative growth, high pod yield with best quality were the interaction between irrigation every 2days and spraying the plants with $\mathrm{MgCO}_{3}$ then the treatment of irrigation every 2days and spraying the plants by kaolin.

\section{REFERENCES}

Abdallah, S. A. M., A. M. El-Gamal, G. Abdel-Nasser and A. I. Ebida (1996). Effect of Folicote Antitranspirant on Water Use, Water Use Efficiency, Yield and Yield Characteristics of Potato Crop Grown in Calcareous Soil." In Proceeding of 4th Arabic Conference, Mini, Egypt, 223-37.

Abd El-Aal, F. S., M. M. Abdel Mouty and A. H. Ali (2008). Combined effect of irrigation intervals and foliar application of some antitranspirants on eggplant growth, fruits yield and its physical and chemical properties. Research J. Agricul. Biol. Sci., 4(5), 416-423.

Abd El - Kader A.M., M. M.S. Saleh and M.A. Ali (2006). Effect of soil moisture levels and some antitranspirants on vegetative growth, leaf mineral content, yield and fruit quality of 
Williams's banana plants. J. Appl. Sci. Res., 2(12): 1248-1255.

Abu-Dahy, Y. M. and M. A. Al-Yuonis (1988). Plant Nutrition. Iraq: Bagdad University, 183.

Asli, S. and P.P. Neumann (2009). Colloidal of clay or titanium dioxide nanopatricles can inhibit leaf growth and transpiration via physical effects on root water transport. Plant Cell and Environment 32, 577-584.

Bittelli, M., M. Flury, G.S. Campbell and E.J. Nichols (2001). Reduction of transpiration through foliar application of chitosan. Agric. Forest Meteorol. 107: 167-175.

Bozkurt, Y., A. Yazar, B. Gencel and S.M. Sezen (2006). Optimum lateral spacing for drip irrigated corn in the

Mediterranean region of Turkey. Agric. Water Manage. 85: 113-120.

Brown, J.D. and M. Lilliand (1964). Rapid determination of potassium and socilium in plant material and soil extracts by phom photometry, proc. Amer. Soc. Hort. Sci., 48:341-346.

Davenport, D. C., K. Uriu and R. M. Hagan (1974). Effects of film antitranspirants on growth. J. Exp. Bot. 25 (85):410419.

Davenport, D. C. (1977). “Antitranspirants Aid Plant Cultivation." American Nurserryman 145 (8): 28-36.

El-Abd, A.A.A. (1996). Studied on the effect of drainage water and/or antitranspirants on growth and some chemical constituents of some Citrus rootstock. M.Sc.Thesis, Fac. of Agric.Kafr El- Shikh, Tanta Univ. Egypt.

Erez, A. and D. M. Glenn (2004). The effect of particle film technology on yield and fruit quality. Acta Hortic. 636:505-508.

Fayza, M. A. Darwesh, Fahima H. Ayoub and O.A.H. EI - Zeiny (2013). Effect of planting date and irrigation periods on physical and chemical properties of eggplant (Solanum melongena) Egypt. J. of Appl. Sci., 28 (8) 555-570.

Gaballah, M.S. and M. Moursy (2004). Reflectants application for increasing wheat plant tolerance against salt stress. Pak. J. Biol. Sci. 7, 956-962.

Gawish, R. A. R. (1992). Effect of Antitranspirants Application on Snap Beans (Phaseolus vulgaris L.) Growth under Different Irrigation Regimes: II, Yield and Water Use Efficiency." Menofia J. Agric. Res. 17: 1309-25.

Gomez, K.A. and A.A. Gomez (1984). Statistical procedures for agricultural research .Joho Wiley and Sons Inc. New York. 680 pp.

Han, J.S. (1990). Use of antitranspirant epidermal coatings for plant protection in China. Plant Dis., 74, 263-266.

Hassan, F.A.S., S. Bazaid and E.F. Ali (2013). Effect of deficit irrigation on growth, yield and volatile oil content on Rosmarinus officinalis $L$. plant. Journal of Medicinal Plants Studies, 1(3): 13-21.

Jakson, M. L. (1973). Soil chemical analysis prentice-Hall of India private limited, New Delhi

Khalel, A. M. S. (2003). Effect of Antitranspirant in Improving Water Status, Growth and Yield of Cucumber. In Proceeding of 2nd Scientific Conference of Plant Production, 49-59.

Khalil, A.M., S.E. Khalil and T.B. Ali (2012). Effect of water stress, antioxidants and humic acid on Capsicum annuum, L. growth, yield and active ingredient under sandy soil conditions. Egypt. J. of Appl. Sci., 27(1): 35-56.

Khalel, A. M. S. (2015). Effect of Drip Irrigation Intervals and Some Antitranspirants on the Water Status, Growth and Yield of Potato (Solanum tuberosum L.) Journal of Agricultural Science and Technology B 5, 15-23 
Moftah, A.E. and A.R.I. Al-Humaid (2005). Effects of antitranspirants on water relations and photosynthetic rate of cultivated tropical plant (Polianthes tuberosa L.). Pol. J. Ecol. 53 (20), 165175.

Nermeen, T. Shanan and E. A. Shalaby (2011). Influence of some chemical compounds as antitranspirant agents on vase life of Monstera deliciosa leaves. African Journal of Agricultural Research Vol. 6(1), pp. 132-139.

Onder, S., S. Bozkurt, G. Sayilikan, D. Onder and M. Kara (2006). Effects of water stress and mulch on grean bean yield and yield components in greenhouse condition. Asian J. Plant Sci. 5: 127-132.

Phene, C.J. and T.A. Howell (1984). Soil sensor control of high frequency irrigation. Trans. ASAE 27 (2), 392396.

Plummer, D.T. (1971). An introduction to practical biochemistry. Mc. Grow Hill Book Company, U k, 278 pp.

Prakash, M. and K. Ramachandran (2000b). Effects of moisture stress and anti-transpirants on leaf chlorophyll. J. Agron. Crop Sci. 184: 153-156.

Rabiza-Swider, J. and E. Skutnik (2004). Effect of light on senescence of cut leaves of Zantedeschia aethiopica Spr. and Hosta Tratt. 'Undulata Erromena'. Folia Hortic., 16(1): 161-166.

Ramadan, A. Y. and M. M. Omar (2017). Effect of Water Regime and Antitranspirants Foliar on Production and Yield of Cabbage in Summer Season. Egypt. J. Soil Sci. 57, 4: 467 476.

Ranney, T.G., N.L. Bassuk and T.H. Whitlow (1989). Effect of transplanting practice on growth and water relation of "colt" cherry trees during reestblishment. Department of Horticulture, Aalabama Agricultural Experimental Station, Auburn University, Auburn, AL 36849, USA.
Sawhney, V. and D.P. Singh (2002). Effect of chemical desiccation at the postanthesis stage on some physiological and biochemical changes in the flag leaf of contrasting wheat genotypes Field Crops Research, 77: 1-6.

Sezen, M., A. Yazar, A. Akyildiz, H. Y. Dasgan and B. Gencel (2008). Yield and quality response of drip irrigated green beans under full and deficit irrigation. Scientia Horticulturae 117 (2008) 95-102.

Singandhupe, R.B., G.G.S.N. Rao, N.G. Patil and P.S. Brahmanand (2003). Fertigation studies and irrigation scheduling in drip irrigation system in tomato crop. (Lycopersicon esculentum L.). Europ. J. of Agron. 19(2): 327-341.

Smesrud, J., B. Mansour, M. Hess and J. Selker (1997). Oregon State University Western Oregon Green Bean Irrigation Guide, vol. 541. Department of Bioresource Enginering, 116 Gilmore Hall, Corvallis, pp. 737-6304 (or 973313906).

Soha, E. Khalil and A. M. Khalil (2015). Effect of water irrigation intervals, Compost and Dry Yeast on Growth, Yield and Oil Content of Rosmarinus officinalis L. plant. American-Eurasian Journal of Sustainable Agriculture. V. (9) September, Pages: 36-51.

Steinberg, S.L., M.J. McFarland and J.W. Worthington (1990). Antitranspirant reduces water use by peach trees following harvest. J. Am. Soc. Hortic. Sci., 115, 20-24.

Wakrim, R., S. Wahbi, H. Tahi, B. Aganchich and R. Serraj (2005). Comparative effects of partial root drying (PRD) and regulated deficit irrigation (RDI) on water relations and water use efficiency in common bean (Phaseolus vulgaris L). Agric. Ecosyst. Environ. 106(2- 3): 275-287.

Yasin, B. T. (1992). Water Stress Physiology in Plant. Mosul, Iraq: Dar Al-kutub Publishing, 22. 
تأثير فترات الري ويعض مضادات النتح على نمو وإنتاجية الفاصوليا تحت نظام الري بالتنقيط في التربة الطينية

\author{
منى سيد احمد جعفر ، فهيمة هلال ايوب \\ أقسام بحوث الخضر - معهة بحوث البساتين - مركز البحوث الزراعية ائية
}

الملخص العربي

تم تنفيذ هذه التجرية في اقسام بحوث الخضر ، معهل بحوث البساتين ، مركز البحوث الزراعية ، محافظة الجيزة ، خلال موسمي الصيف لعامي 2016 و 2017 بهاف تقليل كمية المياه التي يتم اضافتها عن طريق الري ، وزيادة كفاعة ، بهرة استخذام المياه وتحديد الفترة المناسبة لري الفاصوئيا تحت نظام الري بالتنقيط في الاراضي الطينية ،. وقد تضمنت هذه الاراسة ثلاث فترات ري كل (2 و 4 و 8 أيام) تحت نظام الري بالتنقيط ، مع رش خمسة مواد

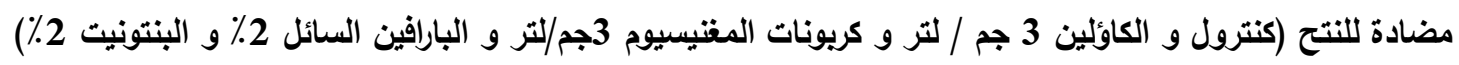
وقث أظهرت النتائج أن زيادة فترات الري من 2 إلى 8ايام أدت إلى انخفاض إجمالي محتوى الماء في الأولق ، ومعدل النتح النسبي ، و تسبيت في زيادة نقص الماء في الورقة. كما أدى تقليل فترة الري من 8 إلى 2 يوم إلى زيادة معنوية

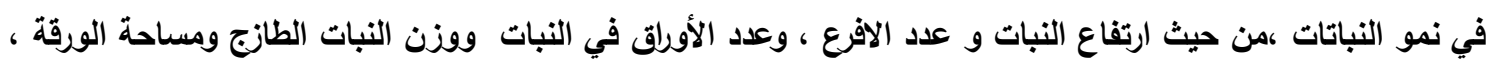

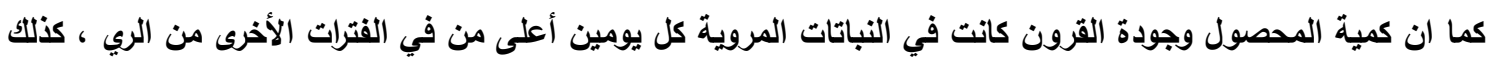
تم الحصول على أعلى قيم لمحتوى النيتروجين والفوسفور والبوتاسيوم في القرون والكلوروفيل في أورلق النباتات المروية

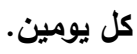

كما ادى رش نباتات الفاصوليا باستخدام كريونات المغنيسيوم يليه بالرش بواسطة الكاولين إلى الحصول على أعلى محتوى مائي إجمالي و أدنى معدل للنتح النسبي وأقل نقص في المياه في الورقة ، كما تم الحصول على أفضل قياسات للنمو، وارتفاع في كمية المحصول وجودة القرون، وتركيز النيتروجين والفوسفور والبوتاسيوم في القرون ومحتوى الكلوروفيل في اولق النباتات التي عوملت بالرش بكريونات المغتيسيوم يليه الرش بالكاولين. من ناحية أخرى ، أدت وترديز

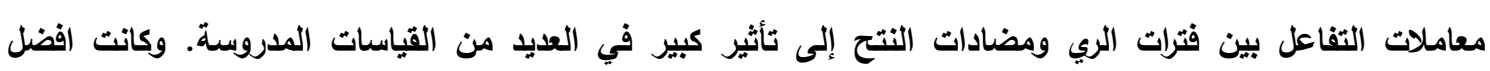
المعاملات للحصول على اقوى نمو خضري واعلى محصول للقرون بمواصفات جيدة عن طريق معاملات التفاعل بين الري كل يومين والرش بكريونات المغنيسيوم يلي ذلك الري كل يومين والرش بمادة الكاؤلين.

$$
\begin{aligned}
& \text { أسماء السادة المحكمين }
\end{aligned}
$$

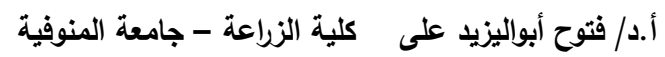


